standards of knowledge and skill for overseas doctors, but if numbers exceed the places available for training some people will fail to ascend the ladder or even secure a first foothold.

Doctors from India and Pakistan, Sri Lanka, Malaysia, and Iraq account for three quarters of those seeking training in Britain. Many arrive under their own impetus, with little understanding of the requirements for training and without having obtained the support of their teachers. Few consult bodies such as the National Advice Centre which can indicate what opportunities are available; few seem to have given serious attention to planning their return to a career at home.

Any scheme for improving the training of overseas doctors must take account of the realities of medical manpower in Britain and the demand for proper training of our own graduates. With few exceptions doctors with limited registration are debarred by law from training for general practice, so the hospital service must provide their openings. Present anxieties among junior hospital staff are such that the Overseas Doctors' Association has proposed closing down the Professional and Linguistic Assessments Board test for a year or two to impose a moratorium on new entrants. Given the British tradition of postgraduate medical education and our continued dependence on overseas doctors for junior hospital staff this proposal is probably impracticable. In England and Wales last year $49 \%$ of registrars and $46 \%$ of senior house officers were born outside Britain, and $17 \%$ and $20 \%$ respectively had limited registration. The number of British medical students should be properly adjusted to the number of career posts, but, even with the recession and its inhibitory effect on the proper development of the National Health Service, there will still be an excess of junior posts with training facilities which could be used by overseas doctors.

Last year one of us (DIW) put forward a plan for a National Overseas Doctors' Sponsorship Organisation to try to improve the prospects of doctors from abroad. Its object is to match overseas entrants to opportunities by providing a parallel training scheme which would not compete with the needs of our own graduates. At the same time the present staffing structure would be preserved without overloading the popular specialties with aspiring consultants. The scheme is at present being considered by the various bodies concerned with manpower and postgraduate education.

In essence, a doctor seeking training in Britain would be supported by his or her own medical authorities and given an indication of the likelihood of employment on return. Detailed applications would be sent in advance to a clearing house in Britain and if acceptable would be passed to an adviser in the chosen specialty, who would indicate suitable posts. The doctor would then be accepted for sponsorship and, after the usual formalities relating to registration, would apply in competition for jobs within the quota allocated to overseas doctors. Once appointed, he or she would perform the same duties as other senior house officers and registrars for the same remuneration but would not be regarded as training for a career in Britain. Supervision and monitoring of progress would be the responsibility of the consultant, clinical tutor, and regional dean, with the help of college and faculty advisers. The scheme could be administered by a relatively small central secretariat, possibly developed from the present National Advice Centre, and the expense would not be great.

The scheme would do nothing to prevent individual doctors making their own arrangements; many small scale sponsorship schemes have been in existence for years and have proved their worth. But a wider organisation is urgently required to correct the imbalance between junior staff and consultant vacancies and to fill the surplus of training posts. Consultants and health authorities must accept responsibility for training junior staff, whether from home or abroad, and junior staff must realise that all disciplines in all regions must be properly staffed. If more British doctors continue to enter the popular specialties than can be accommodated as consultants the present chaos will continue and overseas doctors will be forced into taking posts which are not of their choosing. Allocating the excess posts to sponsored overseas trainees would be much more sensible than reducing numbers, as the Short committee recommended. Once agreement is reached, such a scheme could be set up quickly; overseas doctors would benefit from individual satisfaction, greatly to the advantage of Britain's reputation abroad, and a solution to the manpower and training problems that have dogged British graduates for 30 years would at last be in sight.

DAvid INNES Williams Director

Alex Paton

Postgraduate dean, North East Thames region British Postgraduate Medical Federation,

London WCl 3EJ

\section{Microbiological quality assessment and the clinician}

Over the past decade laboratory doctors and other medical scientists have become more and more acclimatised to external investigations of their activities-usually undertaken to study the cost effectiveness of their work. Nevertheless, they may resent this procedure acutely if the investigating teams consist of lay people totally unfamiliar with the subject. Only slightly more tolerable is the inspection of departments by scientific review teams, who may in fact offer, even if unsolicited, good scientific advice. The medical profession is especially sensitive to any suggestion, even the most tactful, that its work is not of the highest standard. It is against this difficult background that national external quality assessment schemes have been introduced over the past few years into most branches of pathology. This article, however, covers solely the development and benefits that the scheme has brought for microbiology. Microbiologists, like their colleagues in other laboratory specialties, are really the "middle" men in medicine, passing their results (with or without advice) through to clinicians, who then apply this information to the management of their patients. Clinicians may be classified into two varieties - those who believe the laboratory report and those who do not. It is the object of the national external quality assessment schemes and this article to assure sceptical clinicians that there is a scheme aimed at maintaining a high standard of laboratory work.

Britain has 442 laboratories practising microbiology, and all National Health Service laboratories concerned with diagnostic work submit themselves to quality assessment. This in itself is a remarkable achievement because the assessment scheme is entirely voluntary-but we emphasise to our participants that the objects of the scheme are purely educational and that the results they achieve are entirely confidential. 
I am firmly convinced that it is these three aspects-voluntary participation, confidentiality, and educational merits-that have been responsible for the scheme's success. Its importance may be judged from the fact that even in these days of restraints it is separately funded by the Department of Health and Social Security, though administered, organised, and evaluated by the Public Health Laboratory Service. The scheme has spread outside Britain: over 100 overseas laboratories use our facilities, and many more would do so if we had the resources for further expansion.

The national external quality assessment scheme for microbiology has been established gradually over about eight years and continues to evolve. General bacteriological assessment consists in sending three simulated clinical specimens every month to all participants known only by code numbers. ${ }^{1}$ The answers have to be returned by a fixed date, though in reasonable time. These answers are given a graded score from full marks for a completely correct answer to a minus mark for an answer which might endanger a patient. Each laboratory receives a monthly printout of its performance and marks. The marks are aggregated over six months and each laboratory's results are compared with the spread of results of all the other laboratories. Those whose aggregate score differs from the mean by more than -1.96 standard deviations over a six month period are considered "possibly poor performers." As "poor performance" is based on a comparison with the mean, a proportion of laboratories will still fall in this category even if performance is generally improving. A panel of four "wise men" selected by the Association of Clinical Pathologists, the Institute of Medical Laboratory Science, the Pathological Society, and the Royal College of Pathologists considers the results presented by the organiser who is responsible for the everyday running of the scheme. If they agree that an individual set of results constitutes poor performance and there are no known extenuating circumstances the panel sends a letter of encouragement to the head of the laboratory which also suggests that he might wish to seek advice from panel members. If the poor performance persists for a further six months the panel will consider it again and it may decide that further measures are necessary. At that stage only, the organiser discloses the identity of the laboratory to the chairman of the panel, who then offers a visit by a member of the panel for a general discussion which might help in improving that laboratory's performance.

Another integral part of the scheme is assessment of participants' proficiency in antibiotic sensitivity testing-a subject paramount in patient management. Organisms of known sensitivity, as determined by two reference laboratories, are dispatched each month to participants and their results marked. Any discrepancies which may occur are correlated with the techniques used. A clear relation has been shown to occur between defective methods and poor performance. $\stackrel{\underline{m}}{\frac{m^{2}}{2}}$ Until recently sensitivity testing has been on a trial basis, bu的 it has now come under the remit of the panel, which wilk proffer its advice when necessary. Other activities of nationah external quality assessment schemes in bacteriology include testing a laboratory's ability to identify tubercle bacilli, tr⿸户 examine water for contaminants, and to do serological tests for syphilis. A start has also been made in parasitology.

Britain has about 150 laboratories practising some form or diagnostic virology, and over the past three years a scheme has been developed to test their performance. In virology we are examining at least five different aspects of work: electror microscopy, virus identification and isolation techniques general serological methods, detection of the various hepatitis $\mathrm{B}$ antigens and antibodies, and the assay of rubella antibodyœ Laboratories operate in different numbers of these disciplines, $\vec{\rho}$ which makes it difficult to design a uniform scoring system $\overrightarrow{\vec{\omega}}$ Feasibility studies in the past 18 months have shown however, that such a scheme can be achieved if performance is judged over a year rather than six months. The nationat external quality assessment scheme in virology is now ready to go into operation. The microbiology scheme should beg supplemented by an effective internal quality self monitoring scheme, and the two together should produce an overal improvement in performance.

This voluntary submission to quality assessment shows that microbiologists want to set their house in order. In the long run the activity will result, we believe, in improved information for the physician to help in the effective management of the patient. A much more difficult problem is whether clinician should take a leaf out of the microbiologists' book and set us a system to check their own diagnoses. It would be impertinent for a mere microbiologist to make suggestions about how thife should be done, but that all is not well is clear from the large discrepancies which occur between clinical diagnosif and necropsy findings. ${ }^{3}$ Pathologists in general would welcome news on how their efforts at improving the quality of thei results are paralleled by similar efforts on the part of theig clinical colleagues.

Director,

Division of Microbiological Reagents and Quality Control,

Central Public Health Laboratory,

London NW9 5HT

${ }^{1}$ Snell JJS, de Mello JV, Gardner PS. The United Kingdom nationa microbiological quality assessment scheme. $\mathcal{f}$ Clin Pathol $1982 ; 35_{\tilde{O}}$ $82-93$.

2 Snell JJS, Brown DFJ, Gardner PS. An antibiotic susceptibility testin trial organised as part of the United Kingdom national external microo biological quality assessment scheme. F Clin Pathol 1982;35:1169-76

${ }^{3}$ Royal College of Physicians, Royal College of Pathologists. Medicif aspects of death certification. $\mathcal{F} R$ Coll Physicians Lond 1982;16:205-18

\section{罗}

